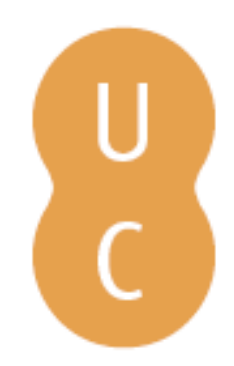

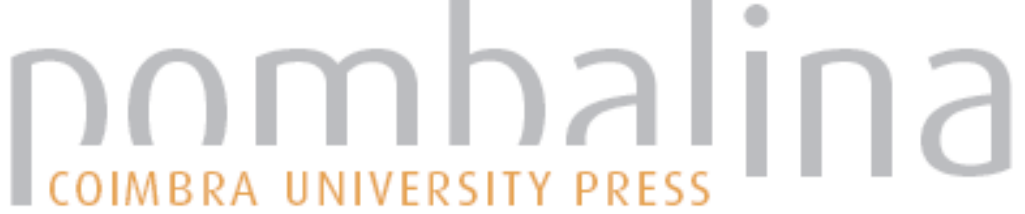

\section{A sátira no teatro de Gil Vicente}

Autor(es): $\quad$ Bernardes, José Augusto Cardoso

Publicado por: Imprensa da Universidade de Coimbra

URL

persistente: URI:http://hdl.handle.net/10316.2/47472

DOI: $\quad$ DOI:https://doi.org/10.14195/978-989-26-1548-6_10

Accessed : $\quad$ 26-Apr-2023 11:34:10

A navegação consulta e descarregamento dos títulos inseridos nas Bibliotecas Digitais UC Digitalis, UC Pombalina e UC Impactum, pressupõem a aceitação plena e sem reservas dos Termos e Condições de Uso destas Bibliotecas Digitais, disponíveis em https://digitalis.uc.pt/pt-pt/termos.

Conforme exposto nos referidos Termos e Condições de Uso, o descarregamento de títulos de acesso restrito requer uma licença válida de autorização devendo o utilizador aceder ao(s) documento(s) a partir de um endereço de IP da instituição detentora da supramencionada licença.

Ao utilizador é apenas permitido o descarregamento para uso pessoal, pelo que o emprego do(s) título(s) descarregado(s) para outro fim, designadamente comercial, carece de autorização do respetivo autor ou editor da obra.

Na medida em que todas as obras da UC Digitalis se encontram protegidas pelo Código do Direito de Autor e Direitos Conexos e demais legislação aplicável, toda a cópia, parcial ou total, deste documento, nos casos em que é legalmente admitida, deverá conter ou fazer-se acompanhar por este aviso.

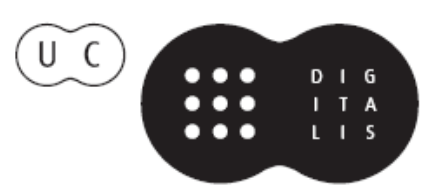



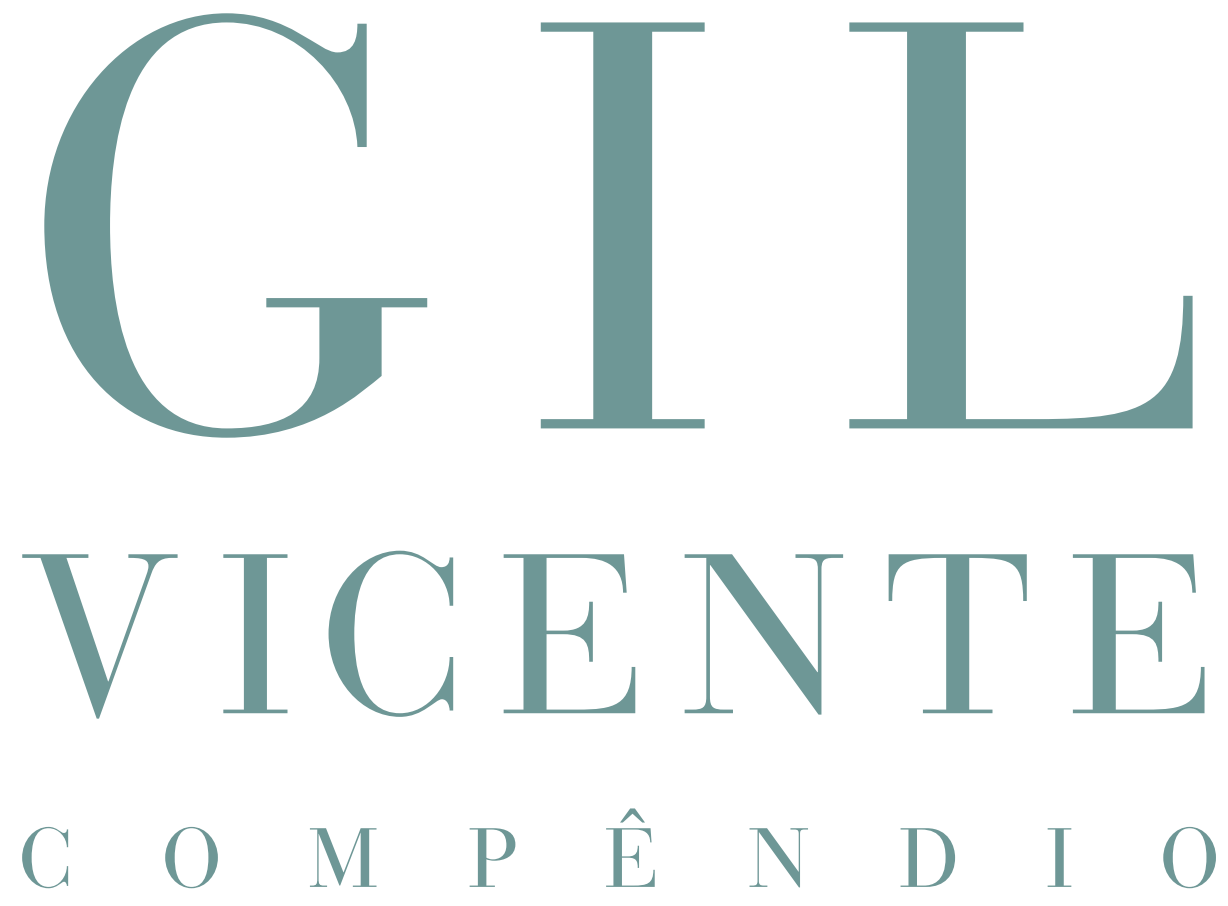

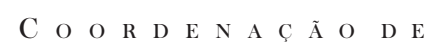

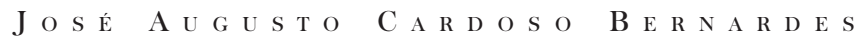

E J O S É C A M Õ E S

CoimbraCompanions

IVPRENSA DA UNIVERSIDADE DE COIMBRA

COIMBRA UNIVERSITY PRESS

IMPRENSA NACIONAL 


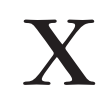

\section{A sátira no teatro de Gil Vicente}

José Augusto Cardoso Bernardes

Centro de Literatura Portuguesa

UNIVERSIDADE DE COIMBRA 
(Página deixada propositadamente em branco) 
Nunca foi tempo em que o engano

tanto valesse com lisonjeria

e a verdade tivesse tão pouca valia

nem menos temessem a Deos soberano.

Festa (II, p. 656.)

\section{INTRODUÇÃO}

A última peça de Gil Vicente (Floresta de Enganos) inicia-se com uma cena enigmática. Nela comparece um Filósofo amarrado a um Parvo. Ao segundo compete vigiar o primeiro, impedindo que este se manifeste na corte. Num determinado momento, porém, o néscio acaba por adormecer, permitindo que o Filósofo profira algumas declarações comprometedoras. Diz este concretamente que esteve preso «en cárcel muy tenebloso» e que esse castigo se deveu apenas ao facto de ter proclamado a Verdade.

Para além dos sentidos concretos que possa ter (relacionados com a peça em que se integra), esta cena ganha um efeito ampliado, obrigando a ler toda a obra do autor numa perspetiva de compromisso. De resto, 35 anos antes, naquela que constitui a sua verdadeira apresentação à corte (Auto Pastoril Castellano), já o dramaturgo tinha vestido a pele insólita de pastor/filósofo (Gil), que se distinguia dos companheiros (rústicos e sensitivos) pela lucidez e sabedoria com que reconhece a Verdade. Chega 
inclusivamente a interpretar o significado profundo do Presépio, à luz das Sagradas Escrituras, para grande espanto dos restantes companheiros, que lhe não conheciam atributos de "lletrudo».

A relação existente entre as duas peças institui, de facto, uma pista de leitura que se pode aplicar à generalidade do teatro vicentino: uma pregação que equivale justamente a um pleito pela Verdade. Esse pleito implica o afastamento relativamente a tudo o que obscurece a mesma Verdade, no plano social, moral ou mesmo teológico: hipocrisias, injustiças, ilusões, opiniões.

A atitude de militância que daqui resulta tem um preço elevado. No auto de 1502, o preço traduz-se sobretudo na solidão: os companheiros de Gil não o reconhecem como um dos seus e tendem para desconfiar da sua sabedoria. Em Floresta de Enganos, o preço é ainda maior: tal como na peça de apresentação, verifica-se o desacompanhamento (a sabedoria e a coragem implicam a vida solitária) mas acrescentam-se a humilhação de quem se vê custodiado por um parvo e o sofrimento cumprido em cárcere afastado da luz, que permite não só o exercício da Razão como a divulgação dos seus efeitos.

A presença da sátira no teatro de Gil Vicente deve ser compreendida à luz deste combate pela Verdade, travado em função do interesse do rei e do reino. Mais do que sublinhar que o dramaturgo de D. Manuel e de D. João III é um "artista de corte», com tudo o que esse estatuto envolve de restritivo, é importante lembrar que estamos perante um artista comprometido com ideais cívicos, incluindo uma ordem teológica, moral e político-social; no mesmo sentido, a dramaturgia vicentina é assinalada pela crítica sistemática a tudo o que possa afetar essa mesma ordem ideal. Não se trata, pois, de uma atitude estritamente corrosiva nem sequer de uma crítica pulsional. Trata-se, outrossim, de uma sátira instrumental, ao serviço de uma causa.

A existência dessa atitude vigilante não requer, de facto, o ataque indiscriminado ao desconcerto do mundo. Em vez dessa atitude radical, encontramos nas peças de Gil Vicente, sobretudo se as considerarmos enquanto conjunto articulado, a identificação de disfunções que podem ser corrigidas e a indicação dos caminhos que se podem seguir para alcançar essa correção. Assim se explica também que, embora sendo importante, a sátira não se assuma como tónica exclusiva do Livro das Obras. Por muito que impressione, pela força e pela frequência com que se manifesta, a sátira 
não deixa de conviver com outras componentes estéticas, em regime de contraposição e de equilíbrio variável. É o que sucede designadamente com o lirismo que, tantas vezes, na economia do Livro das Obras assume o decisivo papel de reconfigurar a realidade corroída pela sátira. Para alcançar esse efeito de equilíbrio e de diálogo estético é, contudo, necessário que o leitor (ou o espectador) se liberte da visão rarefeita da obra do autor (tantas vezes limitada a um pequeno conjunto de peças) e tome a Copilaçam como aquilo que realmente é: um livro inteiro, muito provavelmente construído pelo autor (pelo menos em parte), dotado de evidente coerência orgânica ${ }^{1}$.

Mais do que fazer notar a presença da sátira na dramaturgia vicentina (o que aliás vem sendo feito desde sempre) importa determinar o seu ajustamento em função dos géneros, identificar os focos sobre os quais incide essa tónica, examinar o seu ethos, ou seja, a sua natureza, avaliando o lugar específico que ocupa no conjunto da obra vicentina. Por fim, parece útil avaliar a forma como a sátira se manifesta quando o texto se transforma em espetáculo.

\section{OS GÉNEROS DA SÁTIRA}

Quando se refere a natureza satírica da obra vicentina, pensa-se, sobretudo, em algumas peças mas não em todas. A este propósito, os géneros que imediatamente vêm à colação são a farsa e a moralidade. No primeiro caso, a tónica satírica parece inerente ao próprio género. De tal modo que quando somos colocados perante o Auto da Índia imediatamente nos perguntamos sobre quem mais recai a intenção satírica: se sobre Constança, que dissimuladamente engana o marido, subvertendo deveres morais decisivos, se sobre o pescador que embarca para o Oriente movido pela ambição de enriquecer. O mesmo sucede com uma moralidade como o Auto da Feira. Neste caso, a sátira toca de forma direta e incisiva a figura de Roma (alegoria do papado) mas não deixa imunes os dois pares de feirantes

1 Sobre os fundamentos de coesão e de coerência que presidiram à elaboração do Livro das Obras, é indispensável consultar o estudo de Jorge Alves Osório que consta deste mesmo volume. 
(os compadres e as comadres) insatisfeitos com os respetivos cônjuges e dispostos a trocarem-nos na feira para onde se dirigem.

A diferença entre a forma como a sátira se manifesta num e noutro auto reside justamente na especificidade dos géneros em presença: enquanto na moralidade é clara a oposição entre o mal (alvo da sátira) e o bem, que lhe serve de contraponto, na farsa as fronteiras podem não ser tão claras e a ambiguidade acaba por se instalar. Isto significa nomeadamente que, numa moralidade, quase não existe margem de erro na identificação dos alvos da sátira. A separação entre os dois campos faz-se notar, muitas vezes, através da presença do Diabo e do Anjo, representando um e outro as esferas do mal e do bem. Assim sucede no Auto da Alma, por exemplo. Mesmo que o leitor contemporâneo tenha dificuldade em condenar o apego da Alma a este mundo (envolvendo o consumo e a posse de bens) a verdade é que o dramaturgo sinaliza esse apego como diabólico. As propostas mundanas vêm sempre de Satanás, sendo contrariadas pelo Anjo Custódio que, por sua vez, concentra todos os seus esforços em persuadir a Alma caminhante de que na existência terrena nada existe que justifique demora e apego.

Um caso limite da sátira vicentina surge no Juiz da Beira, exemplo de sottie, género famoso do teatro medieval europeu. Enquanto sot (parvo), Pero Marques é objeto de troça por parte dos cortesãos que dele se riem. No final da peça, porém, é ele quem triunfa, saindo de cena a cantar e a bailar, depois de ter proferido uma série de sentenças "às avessas», colocando em causa os valores e as práticas de justiça que predominam na corte, à qual nunca se rendeu. É possível dizer, deste modo, que o dramaturgo se serve de um género concreto para instituir uma vasta zona de ambiguidade: por um lado, expõe o sot enquanto objeto de crítica; por outro, o objeto transforma-se em sujeito. Mais do que em outras peças, a sátira incide globalmente sobre a corte, considerando a influência nefasta que exerce em todo o reino. O exemplo mais ilustrativo surge na última cena, quando quatro irmãos vêm ao juiz para reivindicar um asno, única herança que o pai lhes legara, ao morrer. Trata-se de um Brigoso, um Amador, um Preguiçoso e um Bailador, emblemas de quatro dos vícios da corte e do Portugal novo, em geral. Citando o asno para a audiência, para 
que ele, "falando», manifeste a sua escolha, o juiz Pêro Marques profere uma sentença típica de um sot, suscetível de provocar o riso dos circunstantes. Na prática, porém, a sentença final tem como efeito negar o asno a todos e a cada um dos herdeiros, envolvendo uma forte censura a todo o Portugal coevo que, nos seus desvios, se mostra indigno de herdar seja o que for do Portugal velho, aqui representado pelo defunto pai dos herdeiros viciosos. Se o progenitor se tinha servido do burro ao longo de uma vida de trabalho, os filhos, tendo enveredado por rumos completamente diferentes, não necessitavam do animal.

\section{OS FOCOS DA SÁTIRA}

No decurso de uma determinada peça, duas freiras sicilianas (por sinal, as únicas freiras que marcam presença no teatro de Gil Vicente) interrogam-se sobre o motivo da insatisfação que parece ter-se instalado por todo o reino: ${ }^{2}$

$\begin{array}{ll}\text { Dorosia } & \text { Por que há i tantos agravados } \\ \text { Domicília } & \text { mais agora que soía? } \\ & \text { Porque nos tempos passados } \\ & \text { todos eram compassados } \\ & \text { e ninguém se desmedia. } \\ & \text { Mas a presunção isenta } \\ & \text { que creceu em demasia } \\ & \text { criou tanta fantesia } \\ & \text { que ninguém nam se contenta } \\ & \text { da maneira que soía. } \\ & \text { Tudo vai fora de termos } \\ & \text { deu o ar na recovagem. } \\ & \text { (II, pp. 144-145.) }\end{array}$

2 Cito por As Obras de Gil Vicente, dir. José Camões, Lisboa, Centro de Estudos de Teatro/Imprensa Nacional-Casa da Moeda, 2002. 
Na sua abrangência, a pergunta de Dorosia e a resposta de Domicília poderiam ser tomadas como uma boa epígrafe da sátira vicentina. De facto, em boa parte, a pergunta parece funcionar como tópico inspirador de uma espécie de inquérito ao reino, que o dramaturgo se propõe levar a cabo ao longo de toda a sua obra. Do mesmo modo, a resposta aqui dada por Domicília constitui uma síntese dos males denunciados. A ideia geral é a de que, nos tempos passados, as pessoas se contentavam com o seu estado. Num determinado momento, porém, irrompe a "presunção isenta" dando azo ao excesso de "fantesia». A acomodação deu então lugar a aspirações insensatas que afetam a ordem social, originando um desconcerto global e profundo.

Este diálogo aplica-se, antes de mais, ao auto em que as personagens se integram (Romagem de Agravados), todo ele centrado na insatisfação de figuras socialmente enraizadas que, dirigindo-se a uma personagem alegórica (Frei Paço), dão conta das suas queixas, sempre ligadas a aspirações insensatas, que vão além da sua condição: um clérigo que quer ser bispo, vilões que querem introduzir os filhos na corte, etc.

No final do auto, Frei Paço, o destinatário das queixas apresentadas, manifesta-se sobre elas deste modo:

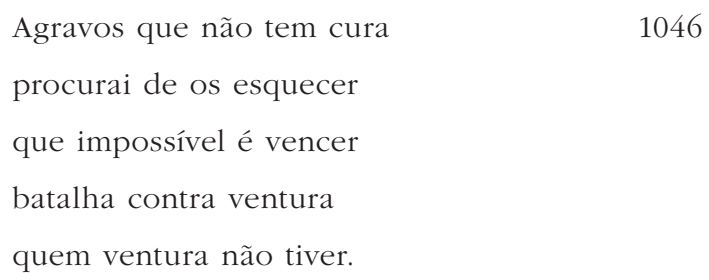

Nesta sentença, a personagem central identifica a «ventura» com a ordem social estabelecida, sustentando implicitamente que ela é tão inamovível como qualquer outro ditame do destino. Os diferentes focos de sátira vão-se desmultiplicando ao longo do Livro das Obras. O facto de, na sua maioria, eles acabarem por corresponder à realidade portuguesa da época tem levado alguns estudiosos (historiadores designadamente) a lerem o teatro vicentino como espelho da realidade sociomental que prevalecia no reino, ao longo do primeiro terço do século XVI. Não se trata de um juízo radicalmente errado. Gil 
Vicente escrevia para um determinado público e gozava inclusivamente do privilégio de conhecer, de perto, esse mesmo público ao qual se dirigia. É, portanto, natural que tivesse presente a realidade que era conhecida dos seus espectadores. Trata-se, no entanto, de uma ilação que necessita de algum matiz. Há que notar, em primeiro lugar, que, na sua maioria, esses mesmos tópicos são comuns ao teatro europeu da época, evidenciando uma substância artística que ultrapassa as fronteiras dos reinos e das línguas; deve sublinhar-se, por outro lado, que, à luz da investigação que vem sendo produzida sobre a realidade social e política, o mais que se pode concluir é que o teatro satírico de Gil Vicente assenta mais na caricatura do que no retrato propriamente dito. Significa isto que os escudeiros que surgem no teatro de Gil Vicente não constituem obrigatoriamente a sinédoque dos escudeiros portugueses da altura, representando mais uma súmula de vícios típicos de alguns escudeiros que se faziam notar pela Europa literária e teatral e também pela Europa sociopolítica.

São muitos os focos de sátira que se podem destacar na criação vicentina. Alguns marcam presença fugaz nos autos; outros mantêm-se constantes, ao longo de toda a obra, refletindo uma preferência ou uma preocupação maior por parte do autor.

Falemos de sátira moral, em primeiro lugar. Neste plano, merece destaque a ambição. Por ela se move boa parte das personagens criticadas, desde clérigos, ávidos de mundanidade, ou gente de baixo estado que renuncia à sua condição na busca de promoção social.

Um outro foco de sátira muito presente no teatro de Gil Vicente é a presunção, que bem pode ser entendida como variante intelectual da ambição. É por presumir que virá a ser a mãe do Redentor que a pastora Sibila recusa as propostas de casamento que lhe são apresentadas. No final do auto, é confrontada com a humildade exemplar da Virgem, que se limitou a entregar-se à vontade de Deus. Presunçosos são ainda os astrólogos criticados no prólogo do Auto da Feira que nada sabem, afinal, para além do que alcança a experiência imediata ou as jovens casadoiras do povo (Isabel de Quem Tem Farelos? ou Inês Pereira do auto do mesmo nome) que resistem aos conselhos das mulheres mais velhas, presumindo que o casamento acima do seu estado lhes trará a realização por que anseiam. 
Já no plano da sátira comportamental (que, algumas vezes, se cruza com a anterior), os exemplos continuam numerosos: aí encontramos apaixonados sofredores que se refugiam em trovas estereotipadas e sem valia (Agravados), nobres que não remuneram quem os serve (Almocreves ou Juiz da Beira), mulheres adúlteras (Índia, Inês Pereira, Almocreves), clérigos dissolutos, incumpridores ou que se consomem nas chamas da paixão (Clérigo da Beira, Barca do Inferno e Físicos), magistrados corruptos (Barca do Inferno e Floresta de Enganos), papas inebriados pelo luxo e pelo poder (Barca da Glória e Feira), etc.

Uma última modalidade pode ser designada por sátira filosófica. Para além dos que tomam o teatro vicentino como suporte documental, outros acercam-se da Copilaçam, na expectativa de nela encontrarem ecos das correntes filosóficas que assinalam a época. Nessa medida se tem falado em algumas variantes de franciscanismo (lulismo ou Devotio Moderna), em agostinismo ou mesmo em erasmismo. Nenhuma destas ilações se revela suficientemente sólida, a ponto de poder considerar-se Gil Vicente como um autor doutrinário, no que essa designação envolve de fundamentação única e de ordenamento estruturado. Mais do que relacionável com qualquer um destes «ismos», a sua ideologia é perfeitamente consentânea com a doutrina católica, no sentido abrangente em que a expressão deve ser tomada, considerando os parâmetros da época. O enaltecimento reiterado da Fé, a devoção à Virgem ou a ideia central da Redenção colocam Gil Vicente numa posição de alinhamento inequívoco relativamente a essa mesma ortodoxia.

São evidentes, por outro lado, as distâncias em relação aos excessos da especulação escolástica, por exemplo (Sermão introdutório de Mofina Mendes), ao excesso de convenções que desvirtuam a natureza humana, sobretudo quando estas se verificam no domínio da Justiça. Deste modo, mais do que uma orientação apologética, o que se verifica é um distanciamento satírico relativamente a determinados exageros.

Algumas vezes, estas variantes de sátira podem entrecruzar-se. Um exemplo de cruzamento entre sátira filosófica e sátira moral é constituído pelos velhos ensandecidos por amor. Para além de outros exemplos menos marcantes, retemos, sobretudo, os casos de Fernandianes, a personagem principal de O Velho da Horta, Brásia Caiada e Filipa Pimenta que, no Triunfo 
do Inverno e em Festa, respetivamente, se dispõem aos maiores sacrifícios para alcançarem a realização amorosa (por imposição do seu jovem amado, Brásia Caiada atravessa descalça a serra da Estrela). Para além de algumas variáveis, a tónica comum consiste na sátira aos que não se conformam com as leis da Natureza (aí residindo a componente filosófica) mas também àqueles que colocam em risco os seus deveres morais por causa de desvarios: é, designadamente, o caso de Fernandianes, que gasta a sua fazenda com a alcoviteira, comprometendo assim o dote da sua jovem filha.

O exemplo mais ilustrativo deste tipo de cruzamento, porém, surge em Festa, peça descoberta apenas no início do século xx e que não figura nas diferentes edições do Livro das Obras. Ao que tudo indica, trata-se de uma peça não representada na corte, o que poderá explicar as liberdades inusitadas que nela ocorrem. Falo de um vilão que descreve, com pormenores, o envolvimento sexual que teve com a mulher do juiz; e falo, sobretudo, da Verdade, figura alegórica que surge em cena, queixando-se de ter sido escorraçada por toda a parte, acolhendo-se à proteção de um determinado senhor. A sátira vai ao ponto de denunciar o desafeto especial à Verdade por parte da corte e do rei. Por fim, é ainda à personagem alegórica que cabe confirmar o desprezo a que é votada:

$$
\begin{aligned}
& \text { Vim-me à corte cuidando achar } \\
& \text { quem me fizesse algum gasalhado } \\
& \text { sem achar nunca ninguém mal pecado } \\
& \text { quem me quisesse somente olhar. } \\
& \text { Oh grã crueldade } \\
& \text { que os tempos de agora tem tal calidade } \\
& \text { que todos no paço já trazem por lei } \\
& \text { que todo aquele que falar verdade } \\
& \text { é logo botado da graça del rei. } \\
& \text { (II, p. 656.) }
\end{aligned}
$$$$
28
$$

Relacionando esta ocorrência de tipo moral e filosófico com aquela que ocorre na cena do Filósofo e do Parvo e ainda com a caracterização de Gil no Pastoril Castellano, encontramos o nexo subordinante da sátira vicentina: 
uma crítica que incide, acima de tudo, sobre a falta de Verdade, entendida no plano da natureza, da sociedade e ainda no plano individual. Fogem à verdade os velhos que procuram o amor fora do seu tempo, o negro que (na Frágua de Amor) se quer tornar branco, os jovens vilões que abandonam os pais e as terras para se tornarem serviçais do rei e dos nobres, os apaixonados que falam e procedem de forma inautêntica, os pilotos sem formação nomeados, por favor fraudulento, para a carreira da Índia (Triunfo do Inverno), a alcoviteira que engana as moças com promessas vãs e imorais.

O reverso da Verdade surge justamente personificado na figura do Diabo. Por duas vezes, na obra vicentina, o vemos em ação neste exato sentido: em Feira, onde assume o disfarce de mercador comum, vendendo o que lhe compram e rejeitando qualquer lógica que não resulte da eficácia do comércio. Quando Roma enuncia o propósito de colher na Feira (de Natal) os bens de que mais carece

Eu venho à feira dereita

382

comprar paz, verdade e fé.

o Diabo, que não dispõe daqueles produtos para vender, responde, então, em tom desmerecedor:
A verdade pera quê?
Cousa que nam aproveita
e avorrece pera que é?
(I, p. 168.)

384

Do mesmo modo, em Alma, o Diabo personifica a lisonja, uma das práticas que mais subverte a Verdade. Normalmente, o Diabo limita-se a reproduzir a lógica do mal (ex post facto) ou a reinterpretar o papel que lhe cabe nos textos sagrados (História de Deus). Parece revelador que da única vez que confere a Satanás o papel ativo de sedutor, Gil Vicente o revele como adulador, apresentando-o insistentemente empenhado em neutralizar a consciência que conduz à Verdade. É esse o sentido dos engodos materiais a que recorre (vestidos, sapatos, ouros, propriedades); 
e é também esse o significado da tese segundo a qual a vida terrena se basta a si mesma:

$$
\begin{aligned}
& \text { Esta vida é descanso } \\
& \text { doce e manso } \\
& \text { nam cureis doutro paraíso. } \\
& \text { Quem vos põe em vosso siso } \\
& \text { outro remanso? } \\
& \text { (I, p. 194.) }
\end{aligned}
$$$$
162
$$

Também neste caso, a dimensão moral se associa à vertente filosófica: está nomeadamente em causa a ideia de que o mundo é enganoso em si mesmo; mas está também em foco a crítica à desregulação dos apetites orientados para as aparências, no esquecimento de que o ser humano não passa de caminhante nesse mesmo mundo de ilusões.

\section{O ETHOS DA SÁTIRA}

Na sua amplitude e na sua relativa virulência, a sátira vicentina pode ser lida como manifesto destrutivo contra a realidade do seu tempo. Pode inclusivamente pensar-se que o desígnio da sátira política não envolve propriamente a submissão a um programa de natureza social, esgotando-se antes na vertente cómica que a anima.

Qualquer destas posições requer, porém, exame mais demorado. De facto, se tomarmos isoladamente alguns excertos do teatro vicentino somos levados a pensar que se está perante um propósito destrutivo. Como não pensar isso mesmo perante a já citada cena do Auto da Feira na qual Roma confessa ter mantido negócios com o Diabo ou como não tirar conclusões idênticas da Barca da Glória, auto tão marcado pela denúncia da conduta dos grandes do mundo, envolvendo o rei, o imperador e o Papa? Ainda assim, essa impressão deve ser contextualizada tendo em consideração os autos em si mesmos e tendo sobretudo em mente uma perspetiva global da Compilação. 
De facto, no próprio Auto da Feira encontramos não apenas a crítica a Roma (a autocrítica, desde logo) mas também o seu contraponto. Depois de indiciado pelo Serafim, Mercúrio explicita-o desenvolvidamente

Dá-lhe Tempo a essa senhora

484

o cofre dos meus conselhos

e podest'ir muit'embora.

Um espelho i acharás

que foi da virgem sagrada

co ele te toucarás

porque vives mal toucada

490

e nam sintes como estás.

E acharás a maneira

como emendes a vida

e nam digas mal da feira

porque tu serás perdida

se nam mudas de carreira.

(I, p. 171.)

Na mesma peça (e na mesma fala) verificamos, assim, não apenas a existência da exposição satírica, em registo de grande clareza, como também a correspondente indicação corretiva, que consiste em mudar de caminho através do exercício da consciência. É esse o significado do espelho da Virgem: aquele que, pelas suas especiais qualidades, permite a devolução de uma imagem fiel, neste caso a imagem dos pecados de Roma.

Pode parecer menos claro o contraponto que se verifica em Barca da Glória. Ele existe, porém. De facto, ao contrário do que sucede com os condenados das outras Barcas, os grandes do mundo têm consciência dos seus pecados. É esse o significado instrumental da presença da Morte, enquanto alegoria. A circunstância de os pecadores verem a Morte permite-lhes não só uma consciencialização profunda das suas faltas como origina a sua atitude de contrição e de prece. Ao mesmo tempo que constitui um poderoso efeito de teatralidade, a visão da Morte representa a verdadeira 
justificação para o desenlace do auto, contemplando a remissão dos condenados, in extremis, apesar da gravidade das suas faltas.

Embora sendo já visível no âmbito de alguns autos (das moralidades, sobretudo), esta dialética faz-se sobretudo sentir no plano macrotextual.

Neste outro plano, merecem destaque duas figuras recorrentes: o pastor e o cavaleiro. Apesar de muito presente desde o primeiro auto, a figura pastoril é muitas vezes situada no domínio do pitoresco. Com efeito, não deixa de ser verdade que boa parte dos pastores vicentinos apresente comportamentos tipificados que não se afastam dos modelos que prevalecem no teatro (imediatamente anterior) de Encina e Fernández. Tanto mais que, pelos traços de rusticidade, a figura do pastor constitui, ela própria, a garantia de grande eficácia teatral, desde logo no plano cómico. Não faltam assim, no teatro de Gil Vicente, rústicos (pastores ou não) que se submetem ao riso de superioridade do público palaciano. É o que sucede, de alguma forma, com o Vaqueiro que, a 7 de junho de 1502, vem saudar o nascimento do príncipe, manifestando a sua admiração boçal pelo espaço em que se encontra, fazendo uso de uma linguagem que se situa nos antípodas dos protocolos palacianos, quando se dirige à rainha, por exemplo. Essa primeira impressão, porém, ganha em ser matizada, logo nesse mesmo auto. De facto, para além do pitoresco de linguagem e de comportamento, o vaqueiro representa uma aproximação genuína do súbdito à família real, que encarece enquanto sucedâneo da família divina. Por outro lado, o nascimento do príncipe é visto como sinal de plenitude, abrangendo todos os reinos hispânicos:

Quien quieres que ño reviente

de placer y gasajado?

De todos tan deseado

este príncipe excelente

oh que rey tiene de ser.

[...]

Oh qué allegría tamaña 


\author{
la montaña \\ y los prados florecieron \\ porque ahora se complieron \\ eñesta misma cabana \\ todas las glórias d'España. \\ (I, p. 19.)
}

No Auto Pastoril Castellano, essa faceta torna-se ainda mais clara: embora convivendo com pastores verdadeiros, Gil revela-se portador de um estatuto especial, no que diz respeito à sabedoria, à perspicácia e às escolhas que faz. Trata-se de um pastor que se desenganou do mundo e que se refugia no contacto com os simples, na reflexão e no conhecimento. Em noite de Natal, é ele quem conduz os companheiros ao presépio de Belém; e é ainda ele quem, para muita admiração dos companheiros (que o sabem nascido em serranias), desvenda o significado profundo do nascimento de Cristo, integrando-o na história da queda e redenção do género humano, tal como surge no Velho e no Novo Testamento.

Refira-se, finalmente, o muito interessante diálogo que no final do Auto da Feira se estabelece entre um Anjo e um grupo de pastores, em torno dos grandes mistérios: "Onde está Deus?» «O que faz Ele»? "Que relação mantém com o mundo?»

sois samicas anjo de Deos.

Quando patiste dos céus

que ficava ele fazendo?

Serafim Ficava vendo o seu gado.

Gilberto Santa Maria, gado há lá?

Oh Jesu como o terá

o senhor gordo e guardado.

E há lá boas ladeiras

como na serra d'Estrela?

SERAFIM Si. 


$$
\begin{array}{cl}
\text { Gilberto } & \text { E a virgem, que fazia ela? } \\
\text { SERAFim } & \text { A virgem olha as cordeiras } \\
& \text { e as cordeiras a ela. } \\
\text { Gilberto } & \text { E os santos de saúde } \\
& \text { todos a Deos louvores? } \\
\text { SERAFIm } & \text { Si. } \\
\text { GILBERTO } & \text { E que léguas haverá } \\
& \text { daqui à porta do paraíso } \\
& \text { onde sam Pedro está? } \\
& \text { (I, pp. 181-182.) }
\end{array}
$$

De resto, Gil Vicente parece especialmente empenhado em fazer dialogar produtivamente os pastores com entidades abstratas, tendo em vista a configuração de uma mensagem que pode funcionar em vários níveis de sentido: num nível imediato, adequado aos destinatários presentes, mas também num plano teológico mais elevado ${ }^{3}$.

É o que sucede ainda no muito curioso Auto da Fé, justamente centrado num diálogo entre "dous pastores simples» e a Fé, ocorrido na capela, nas matinas do Natal. Aí é possível, com simplicidade profunda, explicar aos destinatários ideais o significado da Fé e os caminhos recomendados para nela perseverar:

Fé é amar a Deos só por ele

quanto se puder amar

por ser ele singular

nam por interesse dele.

E se mais queres saber

crer na madre igreja santa

e cantar como ela canta

e querer o que ela quer.

(I, p. 80.)

3 A importância da temática religiosa em Gil Vicente surge sistematizada e analisada, com particular finura e rigor, em estudo de Maria Idalina Resina Rodrigues, que figura neste mesmo compêndio. 
Qualquer destes exemplos (e ainda alguns mais que se poderiam convocar) contribui para solidificar a ideia de que o pastor vicentino representa um contraponto da sátira: vinculado à natureza, constitui o oposto de todos os que dela se afastam, preocupado apenas com a sua subsistência e zeloso do seu gado, significa o contrário de todos os que se deixam conduzir pela ambição, esquecendo os seus deveres morais; autêntico nas palavras, situa-se nos antípodas daqueles que as usam de forma artificiosa; quando, como o emblemático Gil do Auto Pastoril Castellano, se afasta do ruído do mundo para se consagrar à reflexão esclarecida, o pastor funciona como voz profunda de toda a obra vicentina, interpretando uma perspetiva positiva, anverso das muitas vozes e procedimentos que na Compilação se assumem como objeto de sátira.

O mesmo sucede com o cavaleiro que, em Gil Vicente, pode ser visto como antítese do mercador. Mercador é o marido de Constança que, em Índia, embarca com o intuito único de enriquecer à custa das pelejas e dos roubos perpetrados no Rio de Meca. Mercadores são os judeus Latão e Vidal de Inês Pereira, as alcoviteiras de O Velho da Horta e de O Juiz da Beira, todos empenhados em vender uma determinada mercadoria, sem olhar a escrúpulos; mercador é ainda Brás da Mata, que, na primeira parte de Inês Pereira, tenta vender de si próprio uma imagem enganosa, até conseguir conquistar Inês. É ainda mercador o Diabo de Feira, com quem Roma reconhece ter mantido longos e intensos tratos:

Tudo isso tu vendias

e tudo isso feirei

tanto que inda venderei

e outras sujas mercancias

que por meu mal te comprei.

Porque a troco do amor

de Deos te comprei mentira

e a troco do temor

que tinha da sua ira

me deste o seu desamor.

E a troco da fama minha 


$$
\begin{aligned}
& \text { e santas prosperidades } \\
& \text { me deste mil torpidades } \\
& \text { e quantas virtudes tinha } \\
& \text { te troquei pelas maldades. } \\
& \text { (I, pp. 169-170.) }
\end{aligned}
$$

A esta longa galeria de mercadores - personagens que se conduzem pela ambição e pela burla - opõe-se uma outra galeria, onde cabem duas figuras positivas: o pastor, a cujo significado funcional acabo de me referir, e o cavaleiro, que se move exclusivamente pelo cumprimento de uma determinada ética e pela demanda de sentimentos nobres como o Amor. Os casos mais ilustrativos deste paradigma são, sem dúvida, Amadis e Dom Duardos, heróis das peças que têm o mesmo nome. Trata-se de peças construídas sobre um lastro novelesco e, por isso, a trama não apresenta nenhum tipo de novidade. Onde Gil Vicente inova é no processo de composição das personagens. Numa e noutra peça (ainda assim, mais em Dom Duardos) assistimos a desenvolvidos debates em torno da essência do Amor, dos seus efeitos e da sua adaptabilidade às convenções sociais. Em qualquer uma destas duas peças e também noutras como Rubena ou Divisa da Cidade de Coimbra, as personagens representam valores e não interesses. E quando têm que optar, não hesitam em fazê-lo pelos primeiros. Nessa medida se pode concluir que a sátira que atinge tantas outras personagens é compensada através da visão positiva que resulta destas outras duas.

Resta saber até que ponto esta oposição entre uma realidade sombria e uma outra luminosa configura uma tese (a de que Portugal deveria voltar a ser um país de pastores e cavaleiros) e até que ponto essa tese era realista ou utópica.

\section{GIL VICENTE, AUTOR SATÍrico}

Um estudo panorâmico sobre a sátira na literatura portuguesa não pode deixar de conceder ao teatro de Gil Vicente um lugar de destaque. Independentemente dos matizes que se possam introduzir (e já vimos que é necessário introduzir alguns matizes), não há dúvida de que Gil Vicente 
é um dos satiristas mais consistentes e perseverantes da cultura portuguesa e merece lugar destacado numa galeria onde devem figurar trovadores, poetas do Cancioneiro Geral, Fernão Mendes Pinto, D. Francisco Manuel de Melo, Bocage, Tolentino, Eça, Guerra Junqueiro, Camilo Castelo Branco, para ir apenas até ao século xix.

Mas a aura satírica de Gil Vicente justifica analogia com autores que escreveram noutras línguas. Penso em nomes como François Rabelais, que foi quase seu contemporâneo (1494-1553), Francisco Quevedo (1580-1645) ou Jonathan Swift (1667-1745), para citar três dos marcos essenciais da sátira literária na Europa. Tal como sucedeu com a generalidade destes satiristas, também Gil Vicente manteve com o poder uma atitude de relativa independência. De facto, embora a orientação das suas críticas nunca tenha deixado de servir o interesse do rei, é manifesto que esse interesse foi sempre tomado numa perspetiva institucional e não pessoal.

O conhecimento antológico da arte vicentina tem levado a uma certa desfiguração da identidade satírica do autor português. O mais comum é delimitar-se uma só vertente da sua sátira (a sátira aos clérigos, aos magistrados, aos velhos enamorados, etc.) sem nenhum tipo de integração no quadro mais vasto em que a sátira pontual sempre se inscreve. É por via desse procedimento que muitas vezes se confunde sátira com cómico, esquecendo que o último não passa, quase sempre, de um instrumento da primeira. Pode admitir-se que a sátira constitui uma linha definidora do ideário vicentino, em articulação com outras; mas já é mais difícil sustentar que o mesmo acontece com o cómico. Em boa verdade, não existe uma só peça vicentina que se possa considerar cómica na sua essência. Verificámos isso mesmo quando falámos de O Juiz da Beira, auto no qual o riso se transforma afinal em pensamento e em mensagem satírica ou no Parvo da Barca do Inferno, que, podendo fazer rir num primeiro momento, conduz depois ao pensamento.

\section{Conclusão}

Embora seja objeto de investigação em Portugal, Espanha e em muitos outros países, a obra de Gil Vicente é sobretudo conhecida pela sua 
presença no cânone escolar. Como é sabido, a escolarização de um autor implica sempre procedimentos simplificadores. Este procedimento começa logo no número e na natureza dos autos que se dão a ler aos alunos: não podem ser muitos (dois ou três) e, tanto quanto possível, devem estar próximos da sensibilidade e dos interesses dos jovens. Não admira, por isso, que as peças de natureza teológica, que obrigam, desde logo, a um conhecimento das coordenadas histórico-culturais, sejam preteridas em favor de outras, de teor mais realista como Índia ou a Barca do Inferno. Para além da informação documental que podem fornecer sobre a época em que foram escritas, essas peças (ou outras, que bem poderiam alternar com estas duas) convidam a transposições para a atualidade, na escola como nos palcos.

A simplificação traduz-se, depois, na adoção de chaves de leitura. Também não podem ser numerosas e, sobretudo, devem ter um conteúdo assertivo. No caso de Gil Vicente, essas chaves de leitura vêm constando de programas, de manuais e de auxiliares de leitura, pequenas sebentas que prometem eficácia na preparação para os testes, sem exigirem muito esforço. Falo concretamente da ideia de que Gil Vicente fundou o teatro português, esteve sempre ao serviço da corte (no sentido mais subserviente da expressão), é um autor de transição (entre a Idade Média e o Renascimento) e define-se essencialmente pela sua intenção satírica.

Nenhuma destas chaves de leitura é falsa, ou seja, todas revelam um fundo credível e boas possibilidades de exploração no domínio didático. Assim sucede, nomeadamente, com o último tópico, precisamente aquele que dá Gil Vicente como artista satírico. Com efeito, a sátira está longe de ser um acidente no Livro das Obras. É uma referência constante, que se estende desde 1502 a 1536, abarcando grande diversidade de personagens, situações e temas. Para além desta evidência basilar, porém, a componente satírica reveste-se de aspetos que ajudam a individualizar a obra vicentina: articula-se com outras componentes estéticas igualmente importantes (incluindo a utopia), remete para modelos histórico-culturais bem identificados e exprime um compromisso de caráter doutrinal e cívico que, sendo do século XVI, ainda hoje pode ter eco no espírito de leitores e espectadores. 


\section{BibliografiA}

Arden, Heather (1980), Foll's Plays. A Study of Satire in the sottie, Cambridge, Cambridge University Press.

Bernardes, José Augusto Cardoso (2003), "A Sátira da mudança. O peso da história e a leveza da arte no teatro de Gil Vicente», in Revisões de Gil Vicente, Coimbra/Braga, Angelus Novus, pp. 35-52.

- (2006), Sátira e Lirismo no Teatro de Gil Vicente, Lisboa, Imprensa Nacional-Casa da Moeda (2. ed.).

Bloom, Edward and Lilian D. Bloom (1972), Satire's Persuasive Voice, Ithaca, Cornell University Press.

Coelho, António Borges (1994), "A corte portuguesa e os autos de Gil Vicente», in Clérigos, Mercadores, Judeus e Fidalgos, Lisboa, Editorial Caminho, pp. 135-149.

Curto, Diogo Ramada (1998), "A Literatura e o Império. Entre o espírito cavaleiroso, as trocas da corte e o humanismo cívico», in Bethencourt, Francisco, e Chaudhuri, Kirti (dir.), História da Expansão Portuguesa, Lisboa, Círculo de Leitores, vol. I, pp. 434-454.

Dias, João José Alves (1998), Portugal do Renascimento à Crise Dinástica, Lisboa, Editorial Presença (Série "Nova História de Portugal» dirigida por Joel Serrão e Oliveira Marques).

Griffin, Dustin (1994), Satire. A Critical Reintroduction, Kentucky, Kentucky University Press. 